\title{
Role of cytohormonal study in normal pregnancy and in threatened abortion
}

\author{
Shailesh B. Patil, Milind B. Patil* \\ Department of Obstetrics and Gynecology, Ashwini Rural Medical College, Hospital and Research Centre, Solapur, \\ Maharashtra, India
}

Received: 21 March 2018

Accepted: 26 March 2018

*Correspondence:

Dr. Milind B. Patil,

E-mail: drmilindpatil@gmail.com

Copyright: (c) the author(s), publisher and licensee Medip Academy. This is an open-access article distributed under the terms of the Creative Commons Attribution Non-Commercial License, which permits unrestricted non-commercial use, distribution, and reproduction in any medium, provided the original work is properly cited.

\section{ABSTRACT}

Background: It is certain from clinical experience of many that one or more hemorrhages in early pregnancy can still end up in good fetal outcome. So, our study deals with comparison of cytohormonal study in pregnancy and threatened abortion. The study was conducted with the aim of utilizing colpocytogram as a tool in assessing and treating cases of threatened abortion and comparing them with normal pregnant women.

Methods: Patients attending antenatal care unit on outdoor basis and labelled as normal pregnancy cases were considered as control group. The patients of threatened abortion were studied when they were admitted in Gynecology department for indoor treatment. Patients were studied taking into consideration their age, parity, number of abortions, complaints (P/V bleeding, pain in abdomen), gestational age, per abdomen and per vaginal findings and also USG findings and vaginal smear pattern.

Results: Maximum number of patients was present in the age group of 21-25 years in both the groups. While only $13.33 \%$ had normal smear pattern in threatened abortion group. $86.67 \%$ patients in threatened abortion group showed abnormal smear pattern. There is statistically significant difference was found $(\mathrm{p}<0.05)$. There is statistically significant was found $(\mathrm{P}<0.01)$ and indicates good effects of the drug on the vaginal epithelium.

Conclusions: The cytohormonal study acts as a simple, reliable, good, noninvasive method for evaluation of hormonal pattern in normal pregnancy and threatened abortion.

Keywords: Cytohormonal, Hormonal pattern, Normal pregnancy, Threatened abortion

\section{INTRODUCTION}

Since time immemorial, bleeding per vaginum in early months of pregnancy is considered as an ominous sign. It is certain from clinical experience of many that one or more hemorrhages in early pregnancy can still end up in good fetal outcome. So, our study deals with comparison of cytohormonal study in pregnancy and threatened abortion. Normal pregnancy cases are included just for the sake of treating them as control. The occurrence of pregnancy brings about a new adjustment of the interlocking endocrine mechanism. Colpocytogram during pregnancy is a reliable index to a certain extent in assessing the fetoplacental unit. With large amount of Human Chorionic Gonadotrophin (hCG) placenta also secrete oestrogen, progesterone and peptide hormones like hPL, ACTH etc. So, the remarkable feature of pregnancy is the success of the physiological adaptation of a pregnant woman to a most unusual hormonal/endocrine milieu. Progesterone is an important hormone in maintenance of early pregnancy. For first 810 weeks it is secreted by corpus luteum and later on the 
function is taken over by placenta. Oestrogen and progesterone in turn acting on vagina brings about typical changes in vaginal smear. The effects of these hormones are most evident from cytological point of view in the lateral fornices of vagina. Examination of numerous vaginal smears for pregnant women has made it possible to classify smears according to their morphological characteristics. Some of these are regarded as 'Typical of Pregnancy'.

Changes occur in vaginal cytology in cases of progesterone deficiency leading to threatened abortion. In normal pregnancy there is predominance of 'Intermediate cells' which are boat shaped cells with folded edges present in chumps and also called as 'Navicular/ Pregnancy cells'. These are under the effect of hormone progesterone.

In cases of threatened abortion with progesterone deficiency, superficial cells become predominant which are eosinophilic cells with pyknotic nucleus and are under the effect of hormone oestrogen predominantly. Threatened abortion occurs in $20 \%$ of women during early gestation and approximately half of these pregnancies will abort. ${ }^{1,2}$ Various studies reveals that, progesterone can decrease pregnancy loss in women with threatened abortion. ${ }^{3-6}$

In our study, depending upon the type of smear 'Maturation Index' (MI) i.e. relative percentage of Parabasal : Intermediate: superficial cells per 100 cells and 'Karyopyknotic Index' (KPI) i.e. number of cornified cells per 100 cells was made out and accordingly smear was labeled as normal i.e. good progesterone effect or abnormal i.e. mild/moderate/severe progesterone deficiency and treatment was started as per need of each patient in cases of threatened abortion.

The effect of treatment was also evaluated by serial smear study for 2 times if pregnancy continues. The patients were simultaneously assessed with USG examination also.

Though the role of intramuscular progesterone depot preparation in treating threatened abortion is controversial, an attempt has been made to see its effect in this study. The study was undertaken to assess the value of colpocytogram of patients for prognostic significance and further treatment.

The current study was conducted with the aim of utilizing colpocytogram as a tool in assessing and treating cases of threatened abortion and comparing them with normal pregnant women.

\section{METHODS}

The present study was carried out at Department of OBGYN for period of one year. Total 25 normal pregnancy cases and 30 cases of threatened abortion were taken for study.

\section{Selection of cases}

Patients attending antenatal care unit on outdoor basis and labelled as normal pregnancy cases were considered as control group. The patients of threatened abortion were studied when they were admitted in Gynecology department for indoor treatment.

The patients selected in the study had gestational period between 8-20 weeks from the 1st day of last menstrual period. Prior to selection, the cases giving history of Hypertension, Diabetes, Syphilis, Incompetant os were excluded form study to exclude other obvious causes of abortion.

Patients were studied taking into consideration their age, parity, number of abortions, complaints ( $\mathrm{P} / \mathrm{V}$ bleeding, pain in abdomen), gestational age, per abdomen and per vaginal findings and also USG findings and vaginal smear pattern.

On outdoor basis patients of normal pregnancy were investigated for $\mathrm{Hb} \%$, Urine examination (albumin, sugar), Blood group and Rh typing, VDRL test and USG. Patients of threatened abortion were also investigated in similar manner on Indoor basis.

The cases of normal pregnancy and also of threatened abortion (after discharge from ward) were followed on outdoor basis. In threatened abortion the follow up was once a week till the treatment continued and then follow up was as per routine antenatal checkup. In normal pregnancy routine antenatal follow up was done. Patients were followed till deliveries and effect of drug on newborn in the form of presence of any congenital anomaly; limb defects etc. were also noted.

The vaginal smear was repeated twice in cases of threatened abortion in whom pregnancy continued. First smear was taken after admission after bleeding has stopped. Second and third smears were taken after two weeks and four weeks respectively on outdoor basis. While in normal pregnancy only on smear was taken on outdoor basis.

Treatment with Inj. Prolution Depot was started in cases of mild or moderate or severe progesterone deficiency smear on colpocytogram. For good progesterone effect smear only bed rest was given, no hormonal treatment was given. For mild or moderate progesterone deficiency smear $250 \mathrm{mg}$. IM Inj.

Prolution Depot was given. For sever progesterone deficiency smear $500 \mathrm{mg}$ IM Inj. Prolution Depot was started. During the course of treatment if progesterone deficient smear pattern not showed effect of progesterone supplementation then the dose of drug was increased to 
$250 \mathrm{mg}$. twice a week in cases of mild or moderate progesterone deficiency pattern. Thus, the treatment was given wherever it was indicated according to colpocytogram, avoiding the routine use of progesterone in all cases of threatened abortion. In cases of threatened abortions patients were discharged 8 days after cessation of bleeding with advice of bed rest and weekly follow up for treatment.

In cases of missed abortions, the treatment was stopped immediately after diagnosis of missed abortion on USG.

In cases of inflammatory smear, treatment was given in the form of local antibacterial agent and patient responded well.

\section{RESULTS}

Maximum number of patients was present in the age group of 21-25 years in both the groups.

Table 1: Distribution of subjects according to age.

\begin{tabular}{|lll|}
$\begin{array}{l}\text { Age } \\
\text { (years.) }\end{array}$ & $\begin{array}{l}\text { Normal pregnancy } \\
\text { No. of cases }(\%)\end{array}$ & $\begin{array}{l}\text { Threatened abortion } \\
\text { No. of cases }(\%)\end{array}$ \\
\hline $15-20$ & $07(28)$ & $10(33.33)$ \\
\hline $21-25$ & $13(52)$ & $14(46.67)$ \\
\hline $26-30$ & $05(20)$ & $06(20.00)$ \\
\hline Total & $25(100)$ & $30(100)$ \\
\hline
\end{tabular}

It was observed that, in both groups 22 patients (88\% in normal pregnancy and $73.34 \%$ in threatened abortion) were with no previous abortion.
Table 2: Distribution of subjects according to number of previous abortions.

\begin{tabular}{|lll|}
$\begin{array}{l}\text { Previous } \\
\text { abortions }\end{array}$ & $\begin{array}{l}\text { Normal } \\
\text { pregnancy No. of } \\
\text { cases }(\%)\end{array}$ & $\begin{array}{l}\text { Threatened } \\
\text { abortion No. of } \\
\text { cases }(\%)\end{array}$ \\
\hline None & $22(88)$ & $22(73.34)$ \\
\hline 1 & $03(12)$ & $05(16.66)$ \\
\hline 2 & $00(0)$ & $03(10.00)$ \\
\hline Total & $25(100)$ & $30(100)$ \\
\hline
\end{tabular}

In Threatened abortion group $16.66 \%$ patients were with previous one abortion and $10 \%$ with previous two abortions. In normal pregnancy group $12 \%$ patients had single abortion.

Table 3: Distribution of subjects according to normal and abnormal vaginal smear pattern.

\begin{tabular}{|lll|} 
Group & $\begin{array}{l}\text { Normal } \\
\text { smear } \\
\text { No. of cases } \\
(\%)\end{array}$ & $\begin{array}{l}\text { Abnormal } \\
\text { smear } \\
\text { No. of cases } \\
(\%)\end{array}$ \\
\hline Normal pregnancy & $25(100)$ & $00(00)$ \\
\hline Threatened abortion & $04(13.33)$ & $26(86.67)$ \\
\hline
\end{tabular}

All the patients in normal pregnancy showed normal smear pattern. While only $13.33 \%$ had normal smear pattern in threatened abortion group. $86.67 \%$ patients in threatened abortion group showed abnormal smear pattern.

Table 4: Comparison between vaginal smears (KPI and MI) before treatment and after treatment in treated group of threatened abortion (treated with Inj. Proluton depot).

\begin{tabular}{|llll|}
\hline Vaginal smear & $\begin{array}{l}\text { Before treatment } \\
\text { No. of cases }(\boldsymbol{\%})\end{array}$ & $\mathbf{2}^{\text {nd }}$ Week-No. of cases $\mathbf{( \% )}$ & $\mathbf{4}^{\text {th }}$ Week-No. of cases $(\boldsymbol{\%})$ \\
\hline KPI $(\boldsymbol{\%})$ & & $14(82.35)$ & $13(92.8)$ \\
\hline$\leq 10$ & $00(0)$ & $03(17.65)$ & $01(7.2)$ \\
\hline $11-20$ & $14(56)$ & $00(0)$ & $00(0)$ \\
\hline $21-30$ & $04(16)$ & $00(0)$ & $00(0)$ \\
\hline$\geq 31$ & $07(28)$ & & $13(92.8)$ \\
\hline MI & $04(16)$ & $14(82.35)$ & $01(7.2)$ \\
\hline Shift to Midzone & $21(84)$ & $03(17.65)$ & \\
\hline Shift to Right & & & \\
\hline
\end{tabular}

There is statistically significant difference was found ( $p<0.05) .25$ Patients out of 30 received the drug; 8 (32\%) aborted within 1 st week. In remaining 17 patients the distribution according to KPI and MI was as follows;

- Before treatment i.e. on admission 14 (82.35\%) patients had mild progesterone deficiency i.e. KPI 11
$-20 \%$ MI shift to right; 3 (17.65\%) patients showed moderate progesterone deficiency i.e. KPI between 21-30\% MI shift to right.

- After 2 weeks of treatment 14 patients $(82.35 \%)$ showed good progesterone effect i.e. KPI less than or equal to $10 \%$ and MI shift to midzone and 3 patients showed mild progesterone deficiency. 
- After 4 weeks of treatment 13 patients $(92.8 \%)$ had good progesterone effect and one patient $(7.2 \%)$ showed mild progesterone deficiency 3 patients aborted within 2 weeks.
There is statistically significant was found $(\mathrm{P}<0.01)$ and indicates good effects of the drug on the vaginal epithelium.

Table 5: Distribution of cases according to gestational age (by Uterine height in weeks by P/A or P/V examination and USG).

\begin{tabular}{|lllll|}
\hline & \multicolumn{2}{l}{$\begin{array}{l}\text { By Uterine height in weeks by P/A or P/V } \\
\text { examination }\end{array}$} & By USG \\
\hline $\begin{array}{l}\text { Gestational age } \\
\text { (weeks) }\end{array}$ & $\begin{array}{l}\text { Normal pregnancy } \\
\text { No. of cases }(\%)\end{array}$ & $\begin{array}{l}\text { Threatened abortion } \\
\text { No. of cases }(\%)\end{array}$ & $\begin{array}{l}\text { Normal pregnancy } \\
\text { No. of cases }(\%)\end{array}$ & $\begin{array}{l}\text { Threatened abortion } \\
\text { No. of cases }(\%)\end{array}$ \\
\hline $8-10$ & $9(36)$ & $14(46.7)$ & $9(36)$ & $14(46.7)$ \\
\hline $11-12$ & $6(24)$ & $3(10)$ & $6(24)$ & $3(10)$ \\
\hline $13-15$ & $4(16)$ & $4(13.3)$ & $4(16)$ & $4(13.3)$ \\
\hline $16-18$ & $5(20)$ & $6(20)$ & $5(20)$ & $6(20)$ \\
\hline $19-20$ & $1(4)$ & $3(10)$ & $1(4)$ & $3(10)$ \\
\hline
\end{tabular}

In Threatened abortion slightly, higher percentage i.e. $46.67 \%$ was observed in gestational age $8-10$ weeks as compared to other patients in same group. By USG distribution according to gestational age showed similar findings as that of findings by clinical examination. In normal pregnancy one patient showed lying placenta who subsequently had APH (at 32 weeks) and delivered preterm stillbirth baby.

Two missed abortions were detected after two weeks at second USG examination in Threatened abortion group. One patient showed low lying placenta who delivered full term baby by caesarean section. One patient in Threatened abortion group showed signs of placental separation and aborted subsequently.

Table 6: Distribution of subjects according to pregnancy outcome.

\begin{tabular}{|lll|}
\hline $\begin{array}{l}\text { Pregnancy } \\
\text { outcome }\end{array}$ & $\begin{array}{l}\text { Normal } \\
\text { pregnancy } \\
\text { No. of cases } \\
(\%)\end{array}$ & $\begin{array}{l}\text { Threatened } \\
\text { abortion } \\
\text { No. of cases } \\
(\%)\end{array}$ \\
\hline Full term delivery & $20(86.96)$ & $13(43.33)$ \\
\hline Pre term delivery & $02(8.69)$ & $05(16.67)$ \\
\hline Abortion & $01(4.35)$ & $12(40)$ \\
\hline Total & $23(100)$ & $30(100)$ \\
\hline
\end{tabular}

Out of 25 patients in normal pregnancy $20(86.96 \%)$ delivered full term babies. $2(8.69 \%)$ preterm deliveries and in $1(4.36 \%)$ patient abortion was noted. 2 patients lost to follow- up. Out of 30 patients $43.33 \%$ delivered full term babies (including 2 full term IUGR babies). $16.67 \%$ patients had preterm deliveries and $40 \%$ patients aborted ( 2 missed abortions). None of the baby in both groups showed any congenital malformation.

\section{DISCUSSION}

Age and obstetric history in relation with abortion.

In the present study the majority of patients were between age group 21-25 years. In normal pregnancy 52\% and in threatened abortion $46.6 \%$ patients were in this age group. According to Jonhansen A. et al, study risk of abortion increases with increasing maternal age and parity. In the present study, no correlation was observed between risk of abortion and maternal age AND parity. ${ }^{7}$

\section{Symptomatology in threatened abortion}

In the clinical features of threatened abortion, the patient having symptoms suggestive of pregnancy, complains of bleeding per vaginam which usually slight and bright red in colour is and may complain of abdominal pain or backache, but bleeding is usually painless. Pain appears usually following bleeding. ${ }^{8}$ The pain in lower abdomen developed subsequently after admission in 8 cases of threatened abortion out of that $5(62.5 \%)$ aborted within next two- three days.

In Arthur's study, cases of threatened abortion who had complain of pain over sacrum or hypogastrium, majority of them aborted. All these patients had received Inj. Proluton Depot. He also stated that if progesterone is given in such cases it hastens process of abortion. Pain may indicate that contractions have begun, and progesterone will render the myometrium even more sensitive and increase the amplitude and duration of contraction. $^{9}$

\section{Gestational age and abortion rate}

Approximately $80 \%$ of all spontaneous abortions occur before 12 weeks. $^{8}$ According to present study, the 
percentage was slightly higher i.e. $46.67 \%$ at gestational age 8-10 weeks in threatened abortion as compared to other gestational age groups in same study.

\section{USG correlation}

In present study, clinical and USG findings were matched accordingly in both groups. In threatened abortion 2 missed abortions were diagnosed on USG and second USG examination after 2 weeks and both these cases showed abnormal smear pattern on colpocytogram on admission.

In 2 cases placenta previa was noted out of that one patient in normal pregnancy group delivered preterm stillbirth at 8th month of pregnancy.

Other case in threatened abortion group delivered full term baby by caesarean section. One case in threatened abortion showed signs of placental separation and she aborted within 4 days. So, with advent of USG, the diagnosis has become more accurate thus giving a helping hand to colpocytoram. It is also useful to avoid unnecessary use of hormonal treatment.

Funatsu did a study on prognosis of threatened abortion assessed by multivariate analysis and stated that hormonal analysis may be useful in assessing the prognosis in threatened abortion at early gestation (5-6 weeks) while USG findings make an accurate prediction for the prognosis possible after 7 weeks of gestation. ${ }^{10}$

\section{Study of vaginal smear in normal pregnancy and threatened abortion}

In the present study the smears were studied for MI and KPI both groups. During normal pregnancy, extreme midzone shift occurs in MI and KPI comes below $10 \%$. In threatened abortion MI shift to right and increase in KPI occurs. ${ }^{11}$

In threatened abortion due to progesterone deficiency cells become mature i.e. increase in number of superficial cells occur. Superficial cells are larger with $46-60 \mu$ diameter with thin cytoplasm and pyknotic nucleus. They stain eosinophilic and are called as kayopyknotic cells.

The parabasal cells are usually not present in smear during normal pregnancy. These are oval cells with 15-25 $\mu$ diameter and thick cytoplasm. Their presence may indicate intrauterine death.

In the current study the vaginal smear was labelled as normal smear when MI shift to midzone and KPI was below or equal to 10 (good progesterone effect). The smear was labelled as abnormal smear when MI shift to right and KPI increased above 11 these smears were again divided as mild/moderate/severe

\section{Distribution of cases according to smear pattern}

The present findings match with studies by Hassan S. In normal pregnancy all i.e. 25 cases $(100 \%)$ showed normal smear (good progesterone effect) on colpocytogram. ${ }^{12}$

In threatened abortion out of 30 patients (100\%), 4 patients $(13.3 \%)$ showed normal smear. 26 patients $(86.7 \%)$ showed abnormal smear on colpocytogram indicating progesterone deficiency. Mild progesterone deficiency was present in $14(46.6 \%)$ patients, Moderate progesterone deficiency in $4(13.3 \%)$ patients and Severe progesterone deficiency in $8(26.6 \%)$ patients.

According to the present study the comparison between normal and abnormal smears between both groups was statistically significant $(\mathrm{P}<0.05)$. It indicates that colpocytogram acts as a good guide in the diagnosis of threatened abortion

\section{Effect of drug on vaginal smear on colpocytogram}

Total $25(83.33 \%)$ patients received Inj. Proluton Depot.

In $4(16.66 \%)$ patients with good progesterone effect on colpocytogram no treatment with drug was given. Thus, avoiding unnecessary use of progesterone in all cases of threatened abortion. After 8 days of caesarian of bleeding patients were discharged. Next vaginal smears were repeated after 2 weeks and 4 weeks in threatened abortion group whose pregnancy continued.

Out of $25(83.3 \%)$ cases who received the drug $8(32 \%)$ patients aborted within 2 weeks. So repeat smears were taken in remaining 17 cases and the results were as follows. In G.I.M. Swyer et al study, out of 12 cases of threatened abortion with abnormal smear on colpocytogram 7 (58\%) cases showed normal smear after treatment with progesterone. ${ }^{13}$

In our study out of 17 cases of threatened abortion with abnormal smears 13 (76.4\%) showed normal smears after treatment with progesterone. The present study result is comparable with above studies, showing good effect of drug on vaginal smear pattern in cases with progesterone deficiency on colpocytogram.

In the present study out of $14(46.6 \%)$ patients in group of mild progesterone deficiency 11 (78.5\%) patients showed change in smear pattern on colpocytogram. In missed abortion change in smear pattern from severe to moderate progesterone deficiency to smear showing mild progesterone deficiency or good progesterone effect may be because of external supplementation of progesterone which inhibits cornifying action of oestrogen and smear pattern may persist in similar phase till treatment is continued. ${ }^{13}$ 


\section{Comparison of KPI and abortion rate in threatened abortion}

In Prakash $\mathrm{P}$ study, the abortion rate was $15 \%$ when KPI was equal to or less than $10 \% 27 \%$ patients aborted when KPI was between $11 \%$ to $20 \%$. In patients with KPI $21 \%$ to $30 \%$ abortion rate was $100 \%$. When KPI was above $31 \%$ the abortion rate was $100 \% .^{14}$

In the present study abortion rate was $0 \%$ with KPI equal to or less than $10 \%$. Abortion rate was $14.48 \%$ in patients with KPI $11 \%$ to $20 \%$. Abortion rate was $50 \%$ and $100 \%$ when KPI was $21 \%$ to $30 \%$ and above $31 \%$ accordingly. So, the present findings are comparable with other studies. ${ }^{14}$ Similarly when normal and abnormal smear were compared for abortion rate similar findings were noted. These findings may indicate that abortion rate increases significantly in abnormal vaginal smear pattern on colpocytorgram. This may indicate that poor progesterone effect leads to significant increase in abortion rate as reflected by colpocytogram. This may indicate that progesterone is an essential hormone for maintenance of pregnancy.

\section{Pregnancy outcome}

According to Johansen A. et al study was threefold increase in premature labour in cases of threatened abortion. In present study though $16.67 \%$ patients had preterm deliveries, the result is not significant. ${ }^{7}$

\section{Comparison between abortion rate in treated and untreated group of threatened abortion}

In Camilleri A study and G.I.M. Swyer studies the abortion rate was more in treated group while in MaCRae study abortion rate was more in untreated group. ${ }^{9,13,15}$

In the present study also, abortion rate was higher in treated group as compared to untreated group. The present results match with Camilleri and Swyer studies. The abortion rate was higher in treated group may be because of more number of patients with severe progesterone deficiency were present in this group.

If these patients are not calculated the abortion rate in treated group of threatened abortion becomes $16 \%$ only. Progesterone supplementation may prevent abortion in cases of progesterone deficiency.

\section{Effect of treatment}

When effect if treatment was compared with continuation of pregnancy then according to Goldziher study the continuation rate was $75 \%$, in Swyer study the rate was $77.77 \%$ and in our study the rate was $56 \% .^{13}$

This may indicate that Inj. Proluton Depot can prevent abortion in cases of mild to moderate progesterone deficiency. No definitive conclusion was reached as to effectiveness of treatment with Inj. Proluton Depot (17 $\alpha$ $\mathrm{OHP}-\mathrm{C}$ ) in threatened abortion in the current study.

\section{Effect of drug on off springs}

None of the baby had congenital anomaly in both the groups of our study. Off springs who were exposed to drug (17 $\alpha$-OHP-C) in utero were observed for side effects of drug like masculinization of female genitalia, hypospadias in male fetuses and VACTERL syndrome. ${ }^{16}$

In the current study 13 were live births amongst 14 patients who received drug. One was stillbirth which was preterm. None of the baby had any congenital anomaly.

Goldstein in his study studied effect of progestational agents in recurrent miscarriages. He stated that synthetic progesterone preparation may cause masculinization of female fetus and other teratogenic effects. On the other hand, $17 \alpha$-OHP-C progesterone have not shown to increase the prevalence of fetal malformation and also there is no maternal toxicity. ${ }^{17}$

Reijnders FJL studied effect of 17 œ OHP-C during pregnancy to prevent miscarriage and stated that as the relation between progesterone levels and fetal outcome is not clear the drug is not advisable during pregnancy. ${ }^{18}$

According to Rock JA et al amongst term deliveries in patients treated with $17 \propto$ OHP--C, 2.6\% fetuses showed congenital malformations. In his study he noted that our of 30 live births one had meningomyelocele and one had undescended unilateral testis. ${ }^{18}$ Resseuie LJ stated that there is no increased risk of congenital malformation like VACTERL syndrome in fetuses exposed to $17 \alpha-\mathrm{OHP}$ C. ${ }^{19}$

These studies indicated that no trial had a significant treatment effect worst or better than an overall treatment effect.

\section{CONCLUSION}

The cytohormonal study acts as a simple, reliable, good, noninvasive method for evaluation of hormonal pattern in normal pregnancy and threatened abortion.

It appears a good predictor for prognosis of pregnancy as has been seen in this study. But no satisfactory evidence of beneficial effect of progesterone treatment is yet available and required further studies to evaluate the efficacy of drug to prevent the miscarriages. Along with many different regimens including hormonal therapy, bed rest and psychotherapy are also important to improve the outcome in miscarriages. This study comprises very small number of patients but still we could derive the above conclusions. To have firm statement on the role of hormonal therapy in threatened abortion further evaluation is needed. 
Funding: No funding sources

Conflict of interest: None declared

Ethical approval: The study was approved by the Institutional Ethics Committee

\section{REFERENCES}

1. Siriwachirachai T, Piriyasupong $\mathrm{T}$. Effect of Dydrogesterone on Treatment of Threatened Miscarriage: A Systematic Review and MetaAnalyses. Thai J Obstet Gynaecol. 2011;19(3):97104.

2. Pandian RU. Dydrogesterone in threatened miscarriage: a Malaysian experience. Maturitas. 2009;65(1):S47-50.

3. Palagiano A, Bulletti C, Pace MC, DE Ziegler D, Cicinelli E, Izzo A. Effects of vaginal progesteroneon pain and uterine contractility in patients with threatened abortion before twelve weeks of pregnancy. Ann NY Acad Sci. 2004;1034(1):200-10.

4. Sotiriadis A, Papatheodorou S, Makrydimas G. Threatened miscarriage: evaluation and management. BMJ. 2004;329(7458):152-5.

5. Tien JC, Tan TY. Non-surgical interventions for threatened and recurrent miscarriages. Singapore Med J. 2007;48(12):1074-90.

6. Duan L, Yan D, Zeng W, Yang X, Wei Q. Effect of progesterone treatment due to threatened abortion in early pregnancy for obstetric and perinatal outcomes. Early Hum Dev. 2010;86(1):41-3.

7. Sipilä P, Hartikainen Sorri Al, Oja H, Wendt L. Perinatal outcome of pregnancies complicated by vaginal bleeding. BJOG: Int J Obstet Gynaecol. 1992;99(12):959-63.

8. Datta D.C. Text book of Obstetrics, Including Perinatology and Contraception, $3^{\text {rd }}$ Ed, New central book agency. 1992:172.

9. Arthur P. Camileri and N. Gauci: Progesterone Depot in Threatened Abortion, Am J Obstet Gyenecol. 1971;38(1):893-5.

10. Funatsu M, Hirato K, Kawamura E, Chiba H, Moriyama S, Yanaihara T. et al., Study on prognosis of threatened abortion assessed by multivariate analysis. Nippon Sanka Fujinka Gakkai Zasshi. 1990;42(7):689-96.

11. Novak Woodruff Gynaecologic and Obstetric pathology with clinical and endocrine relation: $5^{\text {th }} \mathrm{ed}$, Springer;1963:594-611.

12. Salones H. A vaginal smear study in cases of Threatened Abortion. BJOG: Int $\mathrm{J}$ Obstet Gynaecol,1965;72(3):416-20.

13. Swyer GI, Little V. Progestational agents and disturbances of pregnancy. BJOG: Int $\mathrm{J}$ Obstet Gynaecol. 1965;72(6):104-21.

14. Pratibha $P$, Lalitha KR, Vaginal cytology in Threatened Abortion. J Obstet Gynaecol India. 1982;32:(6):369-71

15. MacRae DJ. Vaginal cytology and the use of progestational agents. BJOG: An International J Obstet Gynaecol. 1965;72(6):1038-9.

16. Rock JA, Wentz AC, Cole KA, Kimball AW, Zacur HA. Fetal malformations following progesterone therapy during pregnancy: A preliminary report. Fertil Steril. 1985;44(1):117-9.

17. Goldstein P, Berrier J, Rosen S, Sacks HS, Chalmers T. A meta-analysis of randomized control trials of progestational agents in pregnancy. British $\mathrm{J}$ Obstet Gynaecol. 1989;96(3):265-74.

18. Reijnders FJ, Thomas CM, Doesburg WH, Rolland R, Eskes TK: Endocrine effects of 17 alphahydroxyprogesterone caproate during early pregnancy: A double-blind clinical treatment. $\mathrm{Br} \mathrm{J}$ Obstet Gynaecol. 1988;95(5):462-8.

19. Resseguie LJ, Hick JF, Bruen JA, Noller KL, O'Fallon WM, Kurland LT. Congenital malformations among offspring exposed in utero to progestins. Fertil Steril. 1985;43(4):514-9.

Cite this article as: Patil SB, Patil MB. Role of Cytohormonal study in normal pregnancy and in threatened abortion. Int J Reprod Contracept Obstet Gynecol 2018;7:1735-41. 